\title{
Argumentation in Foreign Policy Settings
}

\author{
BRITAIN IN 1918, MUNICH IN 1938, \\ AND JAPAN IN 1970
}

\section{ROBERT AXELROD}

\author{
Department of Political Science and \\ Institute of Public Policy Studies \\ University of Michigan
}

This is a study of argumentation in three different kinds of high level, confidential, foreign policy settings: a collegial setting, a bureaucratic setting, and a bargaining setting. The causal and value assertions of the participants were coded using the detailed records of these three settings. The data show to be inadequate a defense/attack model of argumentation in which the participants support their own arguments to make them resistant to attack, while attacking the weak spots in others' stated positions. In fact, there are few assertions which are supported by specific evidence, almost no mutually supported causal arguments, and the assertions which were attacked were no less emphasized than the assertions which were not attacked. More in accord with the data is the novel-arguments approach in which the key factor in persuasive argumentation is the development of arguments which others have not already taken into account.

\section{A rgumentation is a vital part of the policy process when power is shared and when problems are so complex that the participants are not}

AUTHOR'S NOTE: I wish to thank my research assistant and principal coder, Stan Bernstein; my programmers, Ernest Beffel, Leslie Forman, David Gow, Gary Raffel, and Edward Shulaker; my auxiliary coders, Jane Barnard, Joan Kmenta, and Barbara JOURNAL OF CONFLICT RESOLUTION, Vol. 21 No. 4, December 1977

(C) 1977 Sage Publications, Inc. 
sure that their own initial positions are necessarily the best ones. When a policy problem arises, a person's or organization's interests in one or another possible course of action is often far from obvious. Interests must be discovered; or to put it another way, they must be developed piecemeal.

Each of our standard approaches to decision-making recognizes this problem, but each does little to solve it. The unitary rationalactor model (Allison, 1971) and the statistical models of decisionmaking take for granted that the utilities of the entire organization are given in advance. The organizational-process model discusses the role of standard operating procedures and the tendency of decision makers to satisfice rather than optimize their interests, but it does not get into the details of how the consequences of alternatives are estimated. The bureaucratic-politics model treats the policy outcomes as emerging from organizational interests as represented by actors in roles. This is a useful start, but it leaves open the questions of how the role occupants come to see their own interests, and how the somewhat converging and somewhat conflicting interests seen initially by the role occupants get developed through interactions.

The development of interests in a policy choice is done by seeking the causal links between the alternatives and utility. This is what a means-ends analysis is about. Some of these links, or causal paths, come immediately to mind for the decision maker. But he or she is usually aware that not all of them come to mind right away. So, special measures are taken to become aware of more of them-to develop a richer understanding of the consequences of choice, whether collective choice or individual choice within a collective format.

In actual practice, policy makers have several methods for developing these interests, including simply ruminating on them, making lists for themselves, asking their subordinates to write reports, and calling meetings to discuss the issue. This study is concerned with the argumentation process in meetings which are called to deal with major foreign policy problems.

Lewis; and my translators, Steve Reed and Yoko Sakuma. For their help in developing the ideas that went into this paper, I also wish to thank James Beniger, Michael Champion, Michael Cohen, Robyn Davis, Alexander George, Mark Granovetter, Bernard Grofman, Ditsa Kafry, Arnold Kanter, Daniel Okimoto, John Padgett, Tom Palfrey, Seizaburo Sato, Paul Sniderman, and William Zimmerman. I am grateful to Ichiro Suetsugu, Secretary General of the Japanese Council on National Security, for permission to use the transcripts of that group, and to Akio Watanabe and Schien Yoshida for leading me to them. Finally, I wish to thank the National Science Foundation which supported this research under grant SOC74-19773, and the Center for Advanced Study in the Behavioral Sciences where this work was completed. 
Meetings serve many functions, but the functions that are most relevant for developing one's interests in a policy choice are:

(1) the opportunity to talk, since self-expression helps the development of one's own thoughts,

(2) the opportunity to listen to arguments offered by others, and

(3) the opportunity to persuade others of one's own current viewpoint.

A simple paradigm would be that people in committees have initial positions based on the arguments that they have developed on their own or heard before the meeting. Then, they express themselves (not necessarily all that they know or without distortion) to convince others that their initially favored view is best. But they also listen to see if they should be persuaded. That is to say, each recognizes that he may want to change.

March and Simon (1958) warn that the appearance of rational discussion may be exaggerated to minimize organizational conflict. Still, rational discussion is not to be dismissed. It is a vital aspect of the policy process. As Neustadt (1960: 23) points out in speaking of the president, "despite his status he does not get action without argument. Presidential power is the power to persuade." In general, argumentation is important when issues are complex, and its importance is heightened when power is shared.

One of the forms of policy-making in which argumentation plays a vital role is negotiation. After all, most of what happens in negotiation is the assertion of arguments by one side, and the response with other arguments by the other side. Negotiators themselves frequently see negotiations as a search process. They realize that they have only an imperfect understanding of one another's preferences so they pay attention to the other's arguments for several reasons, including a desire to find pairs of items on which concessions may be profitably exchanged (Cross, 1977). The nature of the agreement itself is often based on a formula and details for its implementation (Zartman, 1977). Exactly which formula emerges and how its details are specified is determined through the process of argumentation. Thus an understanding of argumentation is important not only in a decision-making context with flexible preferences, but even in a negotiating context with relatively stable preferences.

This paper is a study of argumentation in high level, confidential, foreign-policy meetings. There will be no attempt to examine the full context of these meetings nor to evaluate the quality of their outcomes. 
Instead, the focus will be on a systematic analysis of the process of argumentation within the meetings themselves. This is not to deny the significance of nonverbal cues within the meetings or the significance of messages between the meetings. It is only to say that much can be learned from what is available: the arguments within the meetings.

The goal is to gain a better understanding of how argumentation is actually conducted among elite decision makers, and thereby achieve a better understanding of the policy process itself, including both decision-making and negotiations.

\section{THE SETTINGS}

Three quite different types of policy groups can be identified. The first is a collegial group in which the members derive their authority not from any organizational constituency, but rather from their personal attributes such as their reputation and their skills in argumentation. The second type of group is the one more typical of American foreign-policy decision-making, in which the members are chosen on the basis of their formal roles in the organizational units which have a stake in the policy issues at hand. This is the kind of group which can be most easily described with the bureaucratic-politics paradigm (Allison, 1971), in contrast to the relatively collegial process more favored by those who found merit in the operations of the ad hoc Executive Committee during the Cuban Missile Crisis, such as George $(1972,1975)$ and Janis (1972). The third kind of setting is a bargaining session in which the participants use threats and promises as well as arguments to infuence each other under conditions of substantial conflict of interest (March and Simon, 1958: 129-135; Walton and McKersie, 1965: 11-125; Lindblom, 1965: 33). Negotiation plays a different role in each of the three types of groups. It is subsidiary in a collegial group, significant in a bureaucratic group, and central in a bargaining group.

The data for this study are derived from the detailed records of one instance of each of these three types of settings. The advantage of selecting three quite different kinds of settings is that it allows one to compare and contrast the modes of argumentation which may appear. If some findings apply to all three such diverse groups, this is good reason to believe that they may have broad applicability. Conversely, if a specific finding applies to only one group but not to the other two, then the differences between the groups can be consulted to see what 
might account for the difference. Let us now turn to the three settings selected for analysis.

The Japanese Council on National Security in 1970 was a clear instance of a collegial group, the British Eastern Committee of 1918 was a typical bureaucratic group, and the negotiations between Chamberlain and Hitler leading to the Munich agreement of 1938 was a salient example of a bargaining setting. Each of these settings involved a small number of participants, at a high level, dealing with policy problems of great importance, under conditions of uncertainty, in the face of differing values and beliefs, where arguments were made and decisions taken without public surveillance.

The Japanese Council on National Security represents a case of collegial deliberations. The Council was a semiofficial advisory group to Prime Minister Eisaku Sato in 1970. Its chairman, Tadao Kusumi, was a close associate of the Prime Minister, and the other members included some of Japan's leading defense intellectuals. It was a collegial group in that the members did not represent specific organizational units or political factions. They had considerable group solidarity based on their earlier work together on Okinawan reversion, and their group cohesiveness was probably reinforced by the norms of Japanese groups (Nakane, 1970). Their main task was to propose a realistic plan for Japanese defense arrangements over the next several years. Recognizing the likelihood of American pullbacks from Asia, and accepting the domestic and international limitations on the growth of Japanese military strength, they focused on the question of deterring potential adversaries and on the role of American bases in Japan. The outcome was a proposal for crisis-stationing: most of the bases would be run by Japan with arrangements for American forces to return in times of crisis. One indication of the significance of the group is that two weeks after they decided on this recommendation, the Director General of the Self-Defense Agency announced for the first time that in times of emergency Japan would let the United States use two air bases that had just been turned over to Japan (Japan Times, December 26, 1970).

The British Eastern Committee represents a case of a standing committee with representation from the major bureaucratic units within the government that had a stake in foreign policy. Being a standing committee of the Imperial War Cabinet it could effectively determine British policy within the range of its authority, the Middle East. From among the many problems it addressed, the one which has been selected for analysis was the question of what to do about British 
involvement in Persia at the end of World War I. The main line of the discussion was whether Britain should withdraw and let Persia "stew in her own juice," continue her active policy of indirect control of the Persian army and finances, or try to conciliate the government and the people of Persia by employing a softer line. The decision after two meetings in December 1918 was to continue the firm British policy, and if necessary to show the Persians that "within the velvet glove is an iron hand" (Eastern Committee, 1918). ${ }^{1}$

The negotiations in September 1938 between Britain and Germany that led to the Munich agreement represent a case of bargaining between nations rather than between individuals or bureaucratic sections within a single nation. It was an extreme case of high conflict of interest and great stress. Hitler had threatened to dismember Czechoslovakia, a nation whose existence was guaranteed by France and indirectly by the United Kingdom. The British Prime Minister, Neville Chamberlain, offered to come to Germany to negotiate with Hitler. The two men met with only a translator on September 15 and again on September 22, and then with five aides on September 23-24, 1938. The main issues of debate were the conditions and timing of the surrender of the Sudeten region of Czechoslovakia. The outcome was the avoidance of an immediate war. This end was forced by the imposition of British and French governmental pressures on the Czechoslovakian government to accept the solution agreed upon by Chamberlain and Hitler.

All three of these settings have highly detailed records of their deliberations. The records of the Japanese Council on National Security are still confidential, but the verbatim transcripts of the meetings have been made available for this study. All sections dealing with policy on foreign policy and defense matters (excluding those dealing exclusively with the estimation of American credibility) were translated and analyzed. The minutes of the Munich negotiations, while written in the third person, are also highly detailed. Both the British and the German versions were published after World War II, and the British version has been used in this analysis (Woodward et al., 1949: 342-351, 463-473, and 499-508). The records of the British Eastern committee consist of verbatim transcripts which have been declassified only recently (Eastern Committee, 1918).

1. For more background on the British Eastern Committee and its deliberations on Persia, see Axelrod (1976: 74-95). 


\section{TURNING DOCUMENTS INTO DATA}

For the purpose of this study, each document was coded sentence by sentence and even phrase by phrase to identify the causal and value assertions made by the speakers. For a full discussion of the documentary coding rules, see Axelrod (1976: 82-84), and for the text of the coding rules themselves, see Wrightson (1976). The fundamental idea is that each causal assertion is coded in terms of its three components: cause, connector, and effect. For example, consider the statement, "Security augments the ability of the Persian government to maintain order." The cause is regarded as "the amount of security in Persia," the effect is regarded as "the extent of the ability of the Persian government to maintain order" and the connector is " + " since there is a positive impact of the cause variable on the effect variable. As an example of a negative causal relationship, consider the statement, "the ability of the British to put pressure on the Persian government inhibits the [extent of the] removal of the better local governors in Persia." Here the connector is "-" since an increase in the ability of the British to apply pressure is asserted to cause a decrease in the removal of the better governors. ${ }^{2}$

Value assertions are those assertions whose effect variable is the utility of a participant. Thus, saying that "chaos in Persia is bad for Britain" is a value assertion, and is coded as if it were "chaos in Persia causes a lowering of British utility." Occasionally assertions (usually assertions of value) are so obvious as not to have to be stated explicitly. In this case they are regarded as assumed assertions. For example, the statement that "the bankruptcy of Persia would harm British security interests in the area" would be coded as two statements: one explicit causal assertion about the effect of bankruptcy on British security interests, and one assumed value assertion about the effect of British security interests on British utility.

Consistency of the coding was achieved by having all of the documents coded by the same person. Reliability was affirmed by comparing the work of this coder with the coding of each of two other coders of known reliability on a test document of 7300 words. ${ }^{3}$

2. Other connectors that are used include: 0 for "no effect," $\Theta$ for "zero or positive effect, "Өfor "zero or negative effect," $M$ for "matters" (i.e., positive or negative effect), and $U$ for "universal" (i.e., any effect is possible).

3. The results are as follows, stated in terms of the average of the current coder with each of the two previous coders. The agreement score on the number of explicit codable assertions in each of the 226 sentences was .82 according to Robinson's measure of agree- 


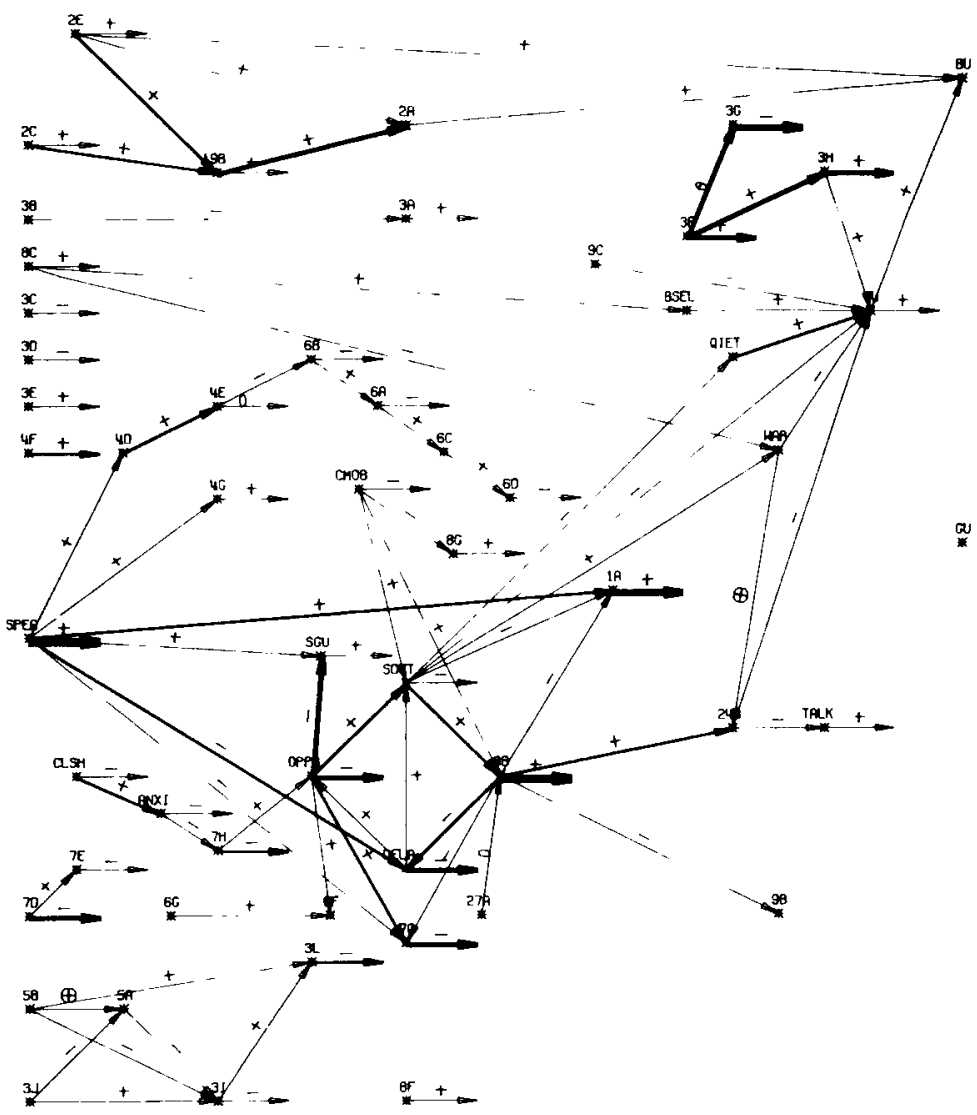

BU - British utility

GU-German utility

JU-Joint British and German utility

ANXI-Anxiety of inhabitants of frontier districts

BSEL-British policy to support the principle of self-determination in the Sudetenland

CLSH-Number of armed clashes on Czechoslovakian-German frontier

CMOB-Czechoslovakian mobilization

DELA-Delay in implemenation of solution to Sudeten question

OPPR-Oppression of Sudeten Germans

QIET_Joint policy to keep political situation quiet during meetings

SDET-Further deterioration of situation in Sudetenland

SPEA-German policy to arrange peaceful return of Germans in Austria and Czechoslovakia

TALK-Direct talks between Hitler and Chamberlain

Figure 1: A Dyadic Model of Negotiation 
1 A - Improvement of Ango-German relations

$2 \mathrm{~A}-$ Hitler's flexibility to define a solution to the problem

2C-German policy to free Germany from treaty of Versailles

2E-Fulfillment by Hitler of promises to Germans (variables 2C, SPEA, 4F)

3A-Racial basis of Nazi party and Germany

3B-German policy of imperialist domination of non-Germans

3C-German policy to unite all Germans in Europe in Germany

3D-German policy to unite German national groups far from Reich with Reich

$3 \mathrm{E}-$ German policy to exclude controversy provoking wound-opening territorial demands (e.g., with France)

$3 F-$ Negotiated settlement of German demands

3G-Expansion of German territorial demands

3H-Germany properly executes negotiated terms

3I--German policy to limit naval fleet to proportion of British naval power

3J-Germany and Britain determination not to make war

3L-German disadvantage vis-a-vis Britian in a war

4D-Demands for secession by Polish, Hungarian, and Ukranian minorities

4E-Dismemberment of Czechoslovakia

4F-German policy to establish German right to colonies

4G-Austrian-German utility

SA-Possibility of war between Britian and Germany

5B-British policy to warn of possibility of war given certain (hostile) acts

6A-Czechoslovakia as spearhead in side of Germany

63-Czechoslovakia alliances with others countries (versus Germany)

6C-Increase in size of German air force (beyond intended size)

6D-German military expenditures

$6 \mathrm{~F}$-Sudeten German resistance to oppression

6G-Growth of power and prestige of German Reich

7D-British policy that Germany and Britain direct appeal to Czechoslovakian parties for armistice

7E-Admonitions for calm to Sudeten-German victims

$7 G$-Outrage to German pride

$7 \mathrm{H}-$ German inactivity in response to Sudeten oppression

$8 \mathrm{~B}-$ Germ policy to solve the Sudeten question by war

$8 \mathrm{C}-$ British policy to announce agreement to separation of Sudetenland and Czechoslovakian constitutional revision

$8 \mathrm{~F}$-Implementation of Sudeten-German separation

8G-German policy to accept British temporary armistice

9B-Ability to stop war machine of Germany

9C-French and British readiness to go to war over the Sudentenland

SGU-Utility of Sudenten-Germans

WAR-Potential for war over Sudetenland

19B-German popular support

24B - War (end of peace in Europe)

27A-World-wide support of Germany

ment (1957). This means that $82 \%$ of the variance in 226 pairs of observations is accounted for by the within-pairs sums of squares. For those assertions that were identified by both coders, complete agreement on three parts of the assertion (i.e., the part of the sentence that contained the cause, the part that contained the sign, and the type of sign) occurred $88 \%$ of the time. Agreement on the identification of variables across assertions occurred $81 \%$ of the time. Agreement on the direct effect of each variable on utility (whether explicit or assumed) occurred $75 \%$ of the time. When a direct effect on utility was noted by two coders, the agreement on the sign was $90 \%$. For further details on the reliability check procedures see Axelrod (1976: 84-86). 
Since the effect variable of one assertion can be the cause variable of another assertion, arguments can be represented as chains of assertions. The easiest way to visualize the complex structure that can result is to represent the concept variables (whether causes or effects) as points, and represent the connectons between them as arrows from the cause concept to the effect concept. Figure 1 is an illustration of Hitler's arguments made during the first meeting of the Munich negotiations. To help keep this large graph legible, the many arrows which go to German utility are represented as short horizontal arrows with no effect variable at their head. As another visual aid, the thickness of arrows is drawn proportional to the number of times the same cause and effect variable are mentioned in an assertion. This graph represents each of the 55 concept variables and 149 assertions Hitler made in the first meeting with Chamberlain. ${ }^{4}$

Table 1 gives some of the basic characteristics of the three settings. Altogether 2191 assertions using 662 different variables were coded. A sense of the size of this data set can be obtained by noting that Figure 1, which shows the arguments used by Hitler in the first meeting of the Munich negotiations, contains only about one-fifteenth of the assertions in the entire data set. As can be seen from Table 1, each text is approximately the same length in English, but the collegialJapanese setting yielded half again as many assertions as did either of the other two settings. Per thousand words of English text, the Japanese setting had both more causal statements and more value statements than the other two. Thus, the basic notions of causation and utility on which the coding scheme is based were found to be highly applicable in this non-Western setting.

\section{THE DEFENSE/ATTACK MODEL}

A plausible image of partisan discussion is that the participants defend their own point of view and attack the arguments of others who have differing policy preferences. In this image, the participants try to build a defense for their own arguments by supporting their assertions with evidence. Or they use mutually supporting arguments to bolster their causal arguments so that if one line of defense fails another will be available. Moreover, in the defense/attack model they

4. A careful study of the graph will show that there are two cycles, or causal loops, involving the variables SDET, 8B, DELA, and OPPR. Such cycles are comparatively rare, and most graphs in the three settings are entirely free of them. For the cognitive implications of the lack of cycles, see Axelrod (1976: 231-239). 


\section{TABLE 1}

Three Settings

\begin{tabular}{lccc}
\hline \hline & $\begin{array}{c}\text { Japanese } \\
\text { Council on } \\
\text { National } \\
\text { Security }\end{array}$ & $\begin{array}{c}\text { British } \\
\text { Eastern } \\
\text { Committee }\end{array}$ & $\begin{array}{c}\text { Anglo-German } \\
\text { Munich } \\
\text { Negotiations }\end{array}$ \\
\hline type of setting & collegial & bureaucratic & bargaining \\
word of English text & 15,300 & 18,600 & 14,000 \\
speakers & 14 & 9 & 4 \\
concept variables & 302 & 186 & 174 \\
assertions & 928 & 610 & 653 \\
$\quad \begin{array}{l}\text { explicit } \\
\text { assumed }\end{array}$ & 741 & 523 & 531 \\
causal assertions per & 187 & 87 & 122 \\
$\quad$ l000 words of English text & 33.3 & 16.1 & 23.8 \\
value assertions per & & & 22.8 \\
\hline 1000 words of English text & 27.4 & 18.1 & \\
\hline
\end{tabular}

seek out and attack the undefended spots in their opponents' arguments in order to overcome them. This defense/attack model may be appealing because of its conflictual nature, but, as we shall now see, it is not very helpful in explaining the data from any of the three cases at hand.

(1) First consider the use of specific examples. For instance, a Japanese participant illustrated his point that the requirement of prior consultations could inhibit timely American reponse to a crisis by mentioning the Soviet invasion of Czechoslovakia in 1968: "Czechoslovakia or something, something new comes up and it [prior consultations] could become very difficult." In fact, however, very few of the hundreds of explicit assertions are supported by specific examples which are cited as evidence (see Table 2, line la). This is somewhat surprising since one would expect that between practical men of politics, concrete historical evidence would be a powerful way of supporting an assertion. An excess of ideological or abstract thinking does not account for this lack of historical evidence, since the most ideologically oriented of all the speakers in the three settings (Hitler and Ribbentrop) actually used proportionally more historical examples than did the other speakers. And so did the speakers who would be expected to be the most abstract thinkers, the members of the Japanese Council on National Security who were professors.

To be generous in the counting of the support by evidence, we might want to include those assertions which are claimed to be generally 
TABLE 2

Defense/Attack Model

\begin{tabular}{ccc}
\hline \hline Japanese & & \\
Council on & British & Anglo-German \\
National & Eastern & Munich \\
Security & Committee & Negotiations \\
\hline
\end{tabular}

1. Proportion of explicit assertions for which there is:
a. historical evidence
b. claimed generality
c. unsupported emphasis

$5 \%$
$1 \%$
$21 \%$
$1 \%$
$5 \%$
$1 \%$
$.4 \%$
$17 \%$

2. Number of mutually supporting causal arguments

3. Average emphasis (by major speakers) of:
a. attacked assertions
.26
b. other assertions
.22

true even if no specific evidence is cited in their support. For example, in justifying his warning about the inviolability of the Anglo-German Naval Agreement, Chamberlain used the form of claimed generality in saying to Hitler, "When two peoples are on the point of conflict with one another they must be perfectly clear in advance of the consequences of such a conflict" (Woodward et al., 1949: 346). The picture remains unchanged, however, when these instances of claimed generality are counted (Table 2 , line $1 \mathrm{~b}$ ). There are still no more than $6 \%$ of all assertions that are supported by either method. This is in sharp contrast to the much larger proportion of assertions which are emphasized without support, either by indications that the speaker firmly believes the statement to be true, or by indications that the speaker thinks the assertion is important (see Table 2, line 1c). ${ }^{5}$

5. The definitions of the four types of emphases are as follows. Specific evidence is the number of specific examples which are cited by the speaker as evidence of the operation of the coded causal principle. Claimed generality is an indication of the speaker's belief that the relationship between cause and effect variables is regular, trustable, or of wide or constant application. Certainty is an indication that a speaker firmly believes the assertion he is making. Importance is an indication that the speaker thinks an assertion is important. It is possible to have more than one indication of a single kind of emphasis and/or 
(2) The very rare use of mutually supporting causal arguments is another fact that is inconsistent with the defense/attack conception of partisan discussion. An argument about how one concept variable affects another is mutually supported if there are two or more independent nontrivial paths (i.e., paths with no intervening variable) by which the first concept is asserted to have an impact on the second concept. The paths are nontrivial if they involve one or more intermediate concepts, and they are independent if they do not share any of these intermediate concepts. While there are many mutually supporting árguments about how concept variables are good or bad (i.e., how they impact on utility), there are, in toto, only four such mutually supporting causal arguments about how one concept variable impacts on a concept variable other than utility (see Table 2 , line 2 ).

(3) The defense/attack image would also suggest that people attack the undefended weak spots in their opponents' arguments, i.e., they tend to attack those assertions that had not already been emphasized. To check this, the major speakers were compared to each other, and each disagreement about how one concept variable affected another was noted. ${ }^{6}$ The results of this analysis (Table 2 , lines $3 a$ and $3 b$ ) show that assertions that are attacked by someone in the same meeting had been no less emphasized than assertions which are not attacked.

In summary, the defense/attack image of argumentation is not very helpful in explaining several important kinds of information: the infrequency of assertions being supported with specific evidence, the infrequency of mutually supported causal arguments, and the lack of greater emphasis on assertions which are attacked compared to assertions which are not attacked. And the above findings are true in all three settings: the collegial-Japanese setting, the bureaucratic-British setting, and the bargaining setting of the Munich negotiations.

more than one type of emphasis for a given assertion. It is also possible for a given single indication of emphasis to apply to more than one assertion. The reliability of the four types of emphases (specific evidence, claimed generality, certainty, and importance) was checked by having one-quarter of the text of each setting independently coded for emphasis by a second coder. The overall intercoder reliability was .70 with no important differences across emphases types or settings.

6. Major speakers are those who had more than $\mathbf{4 0}$ explicit assertions. There are six of this type in the Japanese setting, four in the Eastern Committee and two in Munich; they account for $87 \%, 89 \%$, and $98 \%$ respectively of all assertions in their settings. A disagreement on assertions takes place when two assertions about the same cause and the same effect variables have inconsistent signs, such as when one person says "A promotes $B$ " and the other says "A retards B." 


\section{THE NATURE OF DISAGREEMENTS}

Since the defense/attack model is an inadequate description of what is happening in these meetings, perhaps a better understanding can be obtained by focusing on the nature of specific disagreements the participants have with each other. The most helpful unit of analysis for this purpose is the relationship. A relationship is an asserted connection from a given concept variable to another concept variable, regardless of how many times this connection is asserted, or by how many different speakers, or what the sign of the connection is asserted to be. There is a disagreement over a relationship when there are two or more speakers who use that relationship and their signs are inconsistent.

The striking thing is that there are a very large number of different relationships used in each setting, but only a small proportion of them are disagreed over. There are between three and five hundred different relationships used by the major speakers in each of these settings, resulting in a great richness to the policy discussions in these settings. But there are only a handful of relationships on which the speakers disagree: 29 or $6.0 \%$ in the Japanese Council on National Security, 20 or $6.0 \%$ in the Eastern Committee, and 6 or $1.5 \%$ in the Munich negotiations (Table 3, line 1).

In analyzing these disagreements, it is useful to distinguish between causal and value relationships. As can be seen from Table 3, more than half of the relationships are value relationships, and one of this type is two or three times more likely to be disagreed over than a causal relationship. But even value relationships are not very often disagreed over; less than $11 \%$ of them in each of the three settings. Thus, both types of relationships and all three settings show a low level of disagreement considering that these are face to face, high level, confidential meetings on complex foreign-policy problems.

One potential explanation for this low rate of disagreement is that the participants can disagree with each other without ever having to state directly their disagreement. For example, one person might say that A promotes B and C, both of which are good for Japan, while the other person might say that A promotes D which is bad for Japan. They do not disagree on any of the causal relationships or on any of the value relationships, but the conclusions implicit in what each has said differ concerning the impact of $\mathbf{A}$ on Japanese utility. Taking into account all of the possible effects which can be inferred from the 


\section{TABLE 3}

Disagreements Among Major Speakers

\begin{tabular}{lccc}
\hline & $\begin{array}{c}\text { Japanese } \\
\text { Council on } \\
\text { National } \\
\text { Security }\end{array}$ & $\begin{array}{c}\text { British } \\
\text { Eastern } \\
\text { Committee }\end{array}$ & $\begin{array}{c}\text { Anglo-German } \\
\text { Munich } \\
\text { Negotiations }\end{array}$ \\
\hline $\begin{array}{l}\text { 1. Percent of all relationships } \\
\text { disagreed over }\end{array}$ & $\begin{array}{c}6.0 \% \\
(\mathrm{n}=483)\end{array}$ & $\begin{array}{c}6.0 \% \\
(\mathrm{n}=335)\end{array}$ & $\begin{array}{r}1.5 \% \\
(\mathrm{n}=403)\end{array}$ \\
$\begin{array}{l}\text { 2. Percent of causal relationships } \\
\text { disagreed over }\end{array}$ & $\begin{array}{c}3.9 \% \\
(\mathrm{n}=285)\end{array}$ & $\begin{array}{c}3.6 \% \\
(\mathrm{n}=222)\end{array}$ & $\begin{array}{r}.9 \% \\
(\mathrm{n}=235)\end{array}$ \\
$\begin{array}{l}\text { 3. Percent of value relationships } \\
\text { disagreed over }\end{array}$ & $\begin{array}{l}9.1 \% \\
(\mathrm{n}=198)\end{array}$ & $\begin{array}{c}10.6 \% \\
(\mathrm{n}=113)\end{array}$ & $\begin{array}{r}2.4 \% \\
(\mathrm{n}=168)\end{array}$ \\
\hline
\end{tabular}

assertions made by each speaker, ${ }^{7}$ there can obviously be many more disagreements between speakers than there are disagreements on single relationships. The number of inferrable effects is also greater, however. Altogether, less than $6 \%$ of the effects which can be inferred from the assertions are disagreed over in each setting, and in Munich, only $1.6 \%$ are disagreed over. Therefore, the low proportion of relationships which are disagreed over is not due simply to the possibility that disagreement is more common among what can be inferred compared to what is directly stated.

What is especially striking is that the proportion of disagreement, among both causal and value relationships, is lowest in the Munich negotiations. After all, those negotiations were between the leaders of two nations potentially on the verge of war. What seems to account for the low rate of value disagreement is that Chamberlain sometimes says that an increase in a specific concept variable would be good (or bad) for Britain, and Hitler says it would be the opposite for Germany, but neither says what they think it would be for the other. Thus they do not directly disagree, even though they differ on what should be done about it. If this type of disagreement is included, then the rate of value disagreement in Munich is $12 \%$, virtually the same as in the other two

7. For the mathematics of computing these "total effects," see Axelrod (1976: $61-64,343-348)$. 
groups. ${ }^{8}$ This still leaves unanswered, however, why there is also such a low rate of disagreement among the 235 causal relationships in Munich.

As we have seen, people in all three settings do not disagree with each other at a very high rate. It also happens that they rarely disagree with something they themselves have already said. This is true even though each setting involves several hundred relationships and two or more meetings on the same subject separated by at least a week. ${ }^{9}$ In the collegial-Japanese group this disagreement with something one has already said happened only 19 times, in the bureaucratic-British setting it happened a mere 8 times, and in the bargaining of the Munich setting it happened only three times. Moreover, most of these 30 self-disagreements cannot be attributed to the lapse of time between meetings since 23 of them included self-disagreement within a single meeting.

There are many possible reasons for a person saying something which is inconsistent with a prior statement, including the consideration of a changed context but not its specification, the desire to show agreement with another, and, of course, the actual changing of the mind. The comparatively large number of times one of the Japanese speakers disagreed with himself might well be due to the sense of common purpose of the group, which in turn was promoted by the nature of its advisory role, the strong sense of membership in a shared enterprise, and probably the cultural differences between Japanese and Western groups (Nakane, 1970). The heightened sense of common purpose in the Japanese group probably made it easier for a participant to be less careful about monitoring the consistency of his arguments, easier for him to change his mind, and easier for him to admit a change to others.

\section{CONCLUSION}

We now have seven principal findings regarding argumentation in three high-level foreign-policy groups:

8. This is based on $n=115$, the number of value relationships there would be in the Munich setting if the British, German, and joint utility were regarded as a single-utility variable.

9. The Japanese setting used portions of five meetings spread over six months; the Eastern Committee had two meetings on Persia, separated by 10 days; and the negotiations leading to the Munich settlement took place in three sessions over a period of a week. 
(1) Assertions are infrequently supported by specific evidence.

(2) Causal arguments are almost never mutually supporting.

(3) Assertions which are attacked are no less emphasized than assertions which are not attacked.

(4) Hundreds of different relationships are used in the meetings, but few are disagreed over.

(5) Causal relationships are even less likely than value relationships to be disagreed over, even when unstated implications are taken into account.

(6) There is relatively less disagreement over causal relationships in the Munich negotiations than in the collegial and bureaucratic groups. This was because both the Munich negotiators expressed their own preferences but tended to avoid assertions about what would be good or bad for the others.

(7) Speakers rarely disagree with something they themselves have already said, but this happens most in the collegial-Japanese setting, and least in the Munich negotiations.

These findings, and especially the first three, indicate that the defense/attack conceptualization is not a very adequate way to conceptualize argumentation in policy meetings. 10

More in accord with the data now available is an orientation developed by Burnstein and Vinokur (1973). ${ }^{11}$ Their idea is that to be persuasive an argument must be (1) perceived to be valid by the target and (2) not already known and taken into account by the target. In short, a persuasive argument is a valid argument which is novel. Using the novel-arguments theory, and assuming that the participants in highlevel foreign-policy meetings have initial positions which they are trying to persuade others to adopt, and assuming that they have a judgment about what arguments others will regard as valid, several predictions could be made. In particular, there would be little need for offensive or defensive behavior other than offering arguments which others might not yet have taken into account. Such a prediction does indeed seem to be consistent with the data at hand.

10. This conclusion is not due solely to the fact that assertions are a very small unit of analysis. The result that there is little support and only infrequent disagreement may be partly attributable to the small unit of analysis. The small unit of analysis can not be the sole explanation of the failure of the defense/attack model, however, since disagreement is not more frequent when potential inferences are taken into account. In any case, attacks do not disproportionally tend to be made against the weak spots in the other's arguments.

11. Their theme is developed further with evidence from small-group experiments in a number of subsequent studies: Vinokur and Burnstein (1974), Burnstein and Vinokur (1975), Vinokur et al. (1975), Burnstein and Vinokur (forthcoming). 
The novel-arguments approach also suggests the importance of the very factors that have been stressed by a wide variety of policy analysts: diversity, openness, creativity, acceptance of interpersonal conflict, and avoidance of premature closure. ${ }^{12}$ Unfortunately, the novelarguments approach is not yet specific enough to be able to take us very far in two of the most important tasks that confront the analyst of elite policy-making: the understanding of how decisions emerge from the deliberations of policy groups and the advising on how the policy process can be improved. Moreover, the low rate of disagreement raises the important question of whether high-level policy makers are simply failing to process each other's arguments, or whether they are being strategically sophisticated in ways we do not as yet fully understand.

What is now available for the first time is a set of systematic data on the specific arguments and their structure from several different kinds of high-level foreign-policy settings. The results from this data have already shown that one conception of argumentation is inadequate, and that another conception is potentially useful. In the future, these quantitative results from a collegial, bureaucratic, and bargaining setting can serve to lessen our dependence on anecdotal evidence. By providing the means to evaluate models of the way elite policy groups operate, these results may even inspire the development of new conceptions of how argumentation is conducted, how interests are developed, and how policy is made.

Robert Axelrod is Associate Professor in the Department of Political Science and the Institute of Public Policy Studies of the University of Michigan. He is author of the works The Conflict of Interest and Structure of Decision. He spent 1976-1977 at the Center for Advanced Study in the Behavioral Sciences.

12. See especially Lindblom (1965; 1968), Argyris (1967), George (1972; 1975), Janis (1972), and Cohen and March (1974). 


\section{REFERENCES}

ACKOFF, R. L. and F. E. EMERY (1972) On Purposeful Systems. Chicago: Aldine. ADAMS, J. S. (1976) "The structure and dynamics of behavior in organizational boundary roles," in M. E. Dunnette (ed.) Handbook of Industrial/Organizational Psychology. Chicago: Rand McNally.

ALLISON, G. T. (1971) Essence of Decision: Explaining the Cuban Missile Crisis. Boston: Little, Brown.

ARGYRIS, C. (1967) "Some causes of organizational ineffectiveness within the State Department." Occasional paper no. 2. Washington DC: U.S. Department of State. ARROW, K. (1974) The Limits of Organization. New York: W.W. Norton.

ASHENFELTER, O. and G. JOHNSON (1969) "Bargaining theory, trade unions, and industrial strike activity." Amer. Economic Rev. 59: 35-49.

AXELROD, R. (1977) "Argumentation in foreign policy settings: Britain in 1918, Munich in 1938, and Japan in 1970." J. of Conflict Resolution 21, 4.

_- _ [ed.] (1976) Structure of Decision: the Cognitive Maps of Political Elites. Princeton, NJ: Princeton Univ. Press.

- - (1970) The Conflict of Interest. Chicago: Markham.

BARTOS, O. J. (1977) "Simple model of negotiation: a sociological point of view." J. of Conflict Resolution 21, 4.

- - (1974) Process and Outcome of Negotiations. New York: Columbia Univ. Press. -(1967a) “How predictable are negotiations?” J. of Conflict Resolution 1 1:481-495. (1967b) Simple Models of Group Behavior. New York: Columbia Univ. Press. (1966) Concession-Making in Experimental Negotiation," pp. 3-28 in J. Berger, M. Zeldich, Jr., and B. Anderson (eds.) Sociological Theories in Progress. Boston: Houghton Mifflin.

BAUMOL, W. J. (1961) Economic Theory and Operations Analysis. Englewood Cliffs: Prentice-Hall.

BENTON, A. A. and D. DRUCKMAN (1974) "Constituent's bargaining orientation and intergroup negotiations." J. of Applied Social Psychology 4: 141-150.

BERMAN, M. R. and I. W. ZARTMAN (forthcoming) "How diplomats negotiate: formulas and concessions." International Organization.

BERNSTEIN, B. J. (1976) "We almost went to war." Bull. of Atomic Scientists 2: 13-21. BOULDING, K. E. (1956) The Image. Ann Arbor: Michigan Univ. Press.

BRAITHWAITE, R. B. (1955) Theory of Games as a Tool for the Moral Philosopher. Cambridge, England: Cambridge Univ. Press.

BRAMS, S. J. (1975) Game Theory and Politics. New York: Free Press. 
and D. MUZZIO (1977) "Unanimity in the Supreme Court: a game theoretic explanation of the White House tapes case." Public Choice 30.

_— and F. C. ZAGARE (1977) "Deception in simple voting games." Social Sci. Research 6.

BRAYBROOKE, D. and C. LINDBLOM (1963) Strategy of Decision. New York: Free Press.

BRUNNER, R. D. and B. D. BREWER (1971) Organized Complexity. New York: Free Press.

BURNS, E.L.M. (1970) A Seat at the Table. Toronto: Clarke Irwin.

BURNSTEIN, E. and A. VINOK UR (forthcoming) "Novel argumentation and attitude change: the case of polarization following group discussion."

- - (1975) "What a person thinks upon learning he has chosen differently from others: nice evidence for the persuasive-arguments explanation of choice shifts." J. of Exper. Social Psychology 11: 412-426.

(1973) "Testing two theories about group-induced shifts in individual choice." J. of Exper. Social Psychology 9: 123-137.

BURTON, J. (1969) Communication and Conflict. New York: Free Press.

BUSH, R. R. and F. MOSTELLER (1955) Stochastic Models for Learning. New York: John Wiley.

BUTLER, W. (1971) The Soviet Union and the Law of the Sea. Baltimore: Johns Hopkins Univ. Press.

CACI (1977) Long-Term Forecasts of Potential Middle East Peace Solutions. Arlington, VA: CACI-Inc. Federal.

CAMPBELL, J. C. [ed.] (1976) Successful Negotiation: Trieste 1954. Princeton, NJ: Princeton Univ. Press.

CARR, E. H. (1949) The Twenty-Years Crisis. London: Macmillan.

CARTWRIG HT, D. (1959) "Lewinian theory as a contemporary systematic framework," in S. Koch (ed.) Psychology: a Study of a Science. New York: McGraw-Hill.

CASPARY, W. (1967) “Richardson's models of arms races: description, critique, and alternative model." Inter. Studies Q. 11: 63-88.

CLAUSEWITZ, C. (1832-1969) On War (A. Rapoport, ed.). London: Penguin.

CODDINGTON, A. (1973) "Bargaining as a decision process." Swedish J. of Economics 75: $397-405$.

tions and Uncertainty in Economics. Oxford: Blackwell.

(1968) Theories of the Bargaining Process. Chicago: Aldine.

56: 522-530, reprinted in Young 1975.

COHEN, M. D. and J. G. MARCH (1974) Leadership and Ambiguity. New York: McGraw-Hill.

Conference of the Committee on Disarmament (1970). Final Verbatin Records. Geneva.

- _ (1969) Final Verbatin Records. Geneva.

Confidential Interviews with Conference of Committee on Disarmament Participants (1974).

CONTINI, B. (1968) "Time in bargaining negotiations: some experimental evidence." Amer. Economic Rev. 57: 374-393. 
COOPER, C. (1975) “The iron law of negotiations.” Foreign Policy 19.

CORSON, W. H. (1970) Measuring Conflict and Cooperation Intensity in East-West Relations: a Manual and Codebook. Ann Arbor: Univ. of Michigan, Institute for Social Research. (mimeo)

CROSS, J. G. (1977) "Negotiation as a learning process." J. of Conflict Resolution 21, 4. (1969) The Economics of Bargaining. New York: Basic Books.

(1965) "A theory of the bargaining process." Amer. Economic Rev. 55: 66-94.

DAHL, R. (1976) Modern Political Analysis. Englewood Cliffs, NJ: Prentice-Hall. (1955) "Hierarchy, democracy and bargaining in politics and economics," in

R. Dahl et al., Research Frontiers in Politics and Government. Washington DC: Brookings Institution.

DEAN, A. (1960) "The second Geneva conference on the law of the sea." Amer. J. of Inter. Law 54: 751-789.

(1958) "The Geneva conference on the law of the sea: what was accomplished." Amer. J. of Inter. Law 52: 607-625.

deCALLIERES, F. (1963) On the Manner of Negotiating with Princes. Notre Dame: Notre Dame Univ. Press.

deFELICE, F. B. (1976) "Negotiations, or the art of negotiating," in I W. Zartman, 1976. DEUTSCH, M. (1973) The Resolution of Conflict. New Haven: Yale Univ. Press.

(1968) "Field theory in social psychology," in G. Lindzey and E. Aronson, 1968.

DOUGLAS, A. (1962) Industrial Peacemaking. New York: Columbia Univ. Press.

-__ (1957) "The peaceful settlement of industrial and intergroup disputes." J. of Conflict Resolution 1: 69-81.

DRUCKMAN, D. (forthcoming) "The monitoring function in negotiation: two models of responsiveness," in H. Sauermann (ed.) Contributions to Experimental Economics. Tübingen: Mohr.

(1977a) "New directions and unexplored linkages in negotiation research," in J. A. Wall (ed.) Negotiation Research and Theory. Kent, Ohio: Kent State Univ. Press.

(1977b) "Boundary role conflict: negotiation as dual responsiveness." J. of Conflict Resolution 21, 4.

(1977c) Negotiations: Social-Psychological Perspectives. Beverly Hills: Sage.

(1976) "The person, role and situation in international negotiations," pp. 406-456

in M. G. Hermann (ed.) A Psychological Examination of Political Leaders. New York: Free Press.

___ (1973) Human Factors in International Negotiations: Social Psychological Aspects of International Conflict. Sage Professional Paper 02-020. Beverly Hills: Sage.

(1971a) "On the effects of group representation." J. of Personality and Social Psychology 18: 273-274.

-_ (1971b) "The influence of the situation in inter-party conflict." J. of Conflict Resolution 15: 523-554.

___ (1968) "Prenegotiation experience and dyadic conflict resolution in a bargaining situation." J. of Exper. Social Psychology 4: 367-383.

___ (1967) "Dogmatism, prenegotiation experience, and simulated group representation as determinants of dyadic behavior in a bargaining situation." J. of Personality and Social Psychology 6: 279-290. 
and R. MAHONEY (1977) "Processes and consequences of international negotiations." J. of Social Issues 33.

DRUCKMAN, D. and T. BONOMA (1976) "Determinants of bargaining behavior in a bilateral monopoly situation II: opponent's concession rate and similarity." Behavioral Sci. 21: 252-262.

DRUCKMAN, D., R. ROZElle, R. KRAUSE, and R. MAHONEY (1974) "Power and utilities in a simulated interreligious council: a situational approach to interplay decision-making," in J. Tedeschi (ed.) Perspectives on Social Power. Chicago: Aldine.

DRUCK MAN, D., D. SOLOMON, and K. ZECHMEISTER (1972) "Effects of representational role obligations on the process of children's distribution of resources." Sociometry 35 : $387-410$.

DRUCKMAN, D., K. ZECKMEISTER, and D. SOLOMON (1972) “Determinants of bargaining behavior in a bilateral monopoly situation: opponent's concession rate and relative defensibility." Behavioral Sci. 17: 514-531.

DRUCKMAN, D. and K. ZECKMEISTER (1970) "Conflict of interest and value consensus." Human Relations 23: 431-438.

DURBIN, J. (1970) "Testing for serial correlation in least squares regression when some of the regressors are lagged dependent variables." Econometrica 38: 3 .

- - - and G. S. WATSON (1951) "Testing for serial correlation in least squares regression." Biometrika 38: 173-176.

Eastern Committee (1918) Minutes and Verbatim Annex, Cab 27/24. London: Public Record Office.

ECK HARDT, W. (1965) "War propaganda, welfare values and political ideologies." J. of Conflict Resolution 9: 345-358.

FARQUHARSON, R. (1969) Theory of Voting. New Haven: Yale Univ. Press.

FINK, C. F. (1968) "Some conceptual difficulties in the theory of social conflict." $J$. of Conflict Resolution 12: 412-460.

FORWARD, N. (1971) The Field of Nations. Boston: Little, Brown.

FOSS, W. (1964) "Why the three mile limit?" Navy 7: 32-36.

FRAZER, J. G. (1919) Folklore of the Old Testament. New York: Macmillan.

FREY, R. L. and J. S. ADAMS (1972) "The negotiator's dilemma: simultaneous ingroup and outgroup conflict." J. of Exper. Social Psychology 8: 331-346.

FROLICH, N., J. A. OPPENHEIMER, and O. R. YOUNG (1971) Political Leadership and Collective Goods. Princeton: Princeton Univ. Press.

FRYE, A. (1974) "Decision-making for SALT," pp. 66-100 in M. Willrich and J. Rhinelander (eds.) SALT: the Moscow Agreements and Beyond. New York: Free Press.

GARTHOFF, R. L. (1977) "Negotiating with the Russians: some lessons from SALT," Inter. Security 1: 3-24.

GEORGE, A. L. (1975) "Toward a more soundly based foreign policy: making better use of information." Commission on the Organization of the Government for the Conduct of Foreign Policy. Washington, DC: Government Printing Office: Appendix D.

_- (1972) "The case for multiple advocacy in making foreign policy." Amer. Pol. Sci. Rev. 56: 751-785.

___ et al. (1971) The Limits of Coercive Diplomacy. Boston: Little, Brown.

GRAVEL, M. [ed.] (1971) The Pentagon Papers. Boston: Little, Brown.

HACCOUN, R. and R. J. KLIMOSKI (1975) "Negotiator status and accountability 
source: a study of negotiator behavior." Organizational Behavior and Human Performance 14: 342-359.

HAMERMESH, D. S. (1973) "Who 'wins' in wage bargaining?" Ind ustrial and Labor Relations Rev. 26, 1: 146-149.

HAMNER, W. C. (1974) "The influence of structural, individual and strategic differences on bargaining outcomes: a review," in D. L. Harnett and L. L. Cummings (eds.) Bargaining Behavior and Personality: an International Study.

HIBBS, D. A., Jr. (1974) "Problems of statistical estimation and causal interference in time series regression models," in H. L. Costner (ed.) Statistical Methodology 1973-1974. San Francisco: Jossey-Bass.

HICKS, J. R. (1932) The Theory of Wages. London: Macmillan.

HOLLICK, S. and R. OSGOOD (1974) New Era in Ocean Politics. Baltimore: Johns Hopkins Univ. Press.

HOLSTI, O. R. (1972) Crisis, Escalation and War. Montreal: McGill-Queens Univ. Press.

- _ (1969) Content Analysis for the Social Sciences and Humanities. Reading, MA: Addison-Wesley.

-__ et al. (1965) "Measuring affect and action," J. of Peace Research 1: 170-189.

HOMANS, G. C. (1961) Social Behavior. New York: Harcourt Brace Jovanovich.

HOPMANN, P. T. (1977) "Bargaining within and between alliances on MBFR: perceptions and interactions." Presented at the annual meeting of the International Studies Association, St. Louis, MO.

- - (1974) "Bargaining in arms control negotiations: the seabeds denuclearization treaty." Inter. Organization 28.

(1972) "Internal and external influences on bargaining in arms control negotiations: the partial test ban," in B. M. Russett (ed.) Peace, War and Numbers. Beverly Hills, CA: Sage.

- - and T. C. SMITH (1977) "An application of a Richardson-process model: Soviet-American interactions in the test-ban negotiation 1962-1963." J. of Conflict Resolution 21, 4.

HOPMANN, P. T. and T. KING (1976) "Interactions and perceptions in the test ban negotiations." Inter. Studies Q. 20.

HOPMANN, P. T. and C. WALCOTT (1976) "The impact of international conflict and detente on bargaining in international arms control negotiations: an experimental analysis." Inter. Interactions 2: 189-206.

IKLE, F. C. (1970) "American shortcomings in negotiating with communist powers," in Senate Subcommittee on National Security and International Operations, International Negotiation.

- - (1964) How Nations Negotiate. New York: Harper \& Row.

- - and N. LEITES (1962) "Political negotiation as a process of modifying utilities." J. of Conflict Resolution 6: 19-28.

Institute for Strategic Studies (1969) The Military Balance 1969-1970. London: Institute for Strategic Studies.

JACKMAN, N. (1957) “Collective protest in relocation centers." Amer. J. of Sociology 63: 264-272.

JANIS, I. L. (1972) Victims of Groupthink: a Psychological Study of Foreign-Policy Decisions and Fiascos. Boston: Houghton Mifflin. 
Japan Times (1970) December 26.

JENSEN, L. (1968) “Approach-avoidance bargaining in the test ban negotiations." Inter. Studies Q. 12: 152-160.

-__ "Soviet American bargaining behavior in post-war disarmament negotiations." J. of Conflict Resolution 6: 522-541.

JER VIS, R. (1970) The Logic of Images in International Relations. Princeton: Princeton Univ. Press.

KAHN, A. S. and J. W. KOHLS (1972) "Determinants of toughness in dyadic bargaining." Sociometry 35: 305-315.

KALB, M. and B. KALB (1974) Kissinger. New York: Dell.

KELLEY, E. W. (1970) "Bargaining in coalition situations," in Kelley et al. (eds.) The Study of Coalition Behavior. New York: Holt, Rinehart \& Winston.

KISSINGER, H. A. (1969) "The Vietnam negotiations." Foreign Affairs 47: 211-234. (1961) The Necessity of Choice. New York: Harper \& Row.

KLIMOSKI, R. J. (1976) “Representatives' negotiation behavior as a function of individual and group factors: a review of research." Columbus: Ohio State University. (mimeo)

_- (1972) "The effect of intragroup forces on intergroup conflict resolution." Organizational Behavior and Human Performance 8: 363-383.

- — and R. A. ASH (1974) "Accountability and negotiation behavior." Organizational Behavior and Human Performance 11: 409-42S.

KNOUSE, S. and R. J. KLIMOSKI (1976) "An operant conditioning investigation of negotiating behavior." Presented at the nineteenth conference of the Midwest division of the Academy of Management, St. Louis, MO.

KNOWLES, K. G. (1954) "Strike proneness and its determination." Amer. J. of Sociology 60: 213-229.

KNOX, R. and R. L. DOUGLAS, (1971) "Trivial incentives, marginal comprehension, and dubious generalizations from prisoners' dilemma studies." J. of Personality and Social Psychology 20: 160-165.

KUHN, H. W. and A. W. TUCKER [eds.] (1953) Contributions to the Theory of Games 2. Princeton: Princeton Univ. Press.

KUHN, T.S. (1962) The Structure of Scientific Revolutions. Chicago: Univ. of Chicago.

LAMM, H. and N. KOGAN (1970) "Risk-taking in the context of intergroup negotiation." J. of Exper. Social Psychology 6: 351-363.

LANDSBERGER, H. A. (1955) "Interim report on a research project on mediation." Labor Law Rev. 6: 552-560.

LEONARD, J. (1974) Interview.

LEVY-STRAUSS, C. (1949) The Elementary Structure of Kinship. Paris: Presses Universitaire Françaises.

LEWIN, K. (1968) The Conceptual Representation and Measurement of Psychological Forces. New York: Johnson Reprint.

- _ (1951) Field Theory in Social Science: Selected Theoretical Papers. D. Cartwright (ed.) New York: Harper Bros.

_- (1936) Principles of Topological Psychology. F. Heider and G. Heider [trans.] New York: McGraw-Hill.

_- (1935) A Dynamic Theory of Personality: Selected Papers. D. Adams and K. Zener [trans.] New York: McGraw-Hill. 
LINDBLOOM, C. E. (1968) The Policy-Making Process. Englewood Cliffs, NJ: Prentice-Hall.

___ (1965) The Intelligence of Democracy: Decision Making Through Mutual Adjustment. New York: Free Press.

LINDZEY, G. and E. ARONSON [eds.] (1968) The Handbook of Social Psychology. Reading, MA: Addison-Wesley.

LOVE, R. L., R. M. ROZELLE, and D. DRUCKMAN (1977) "Resolving conflicts of interest and ideology: a simulated political decision making." Presented at the annual meeting of the American Psychological Association, San Francisco.

LOWI, T. J. (1963) "Bases in Spain," in H. Stein (ed.) American Civil-Military Decisions: a Book of Case Studies. Tuscaloosa: Univ. of Alabama Press.

LUCE, R. D. and H. RAIFFA (1957) Games and Decisions. New York: John Wiley.

McGRATH, J. E. (1966) "A social psychological approach to the study of negotiation," in R. Bowers (ed.) Studies on Behavior in Organizations: a Research Symposium. Athens: Univ. of Georgia Press.

- - and J. W. JULIAN (1963) Interaction process and task outcomes in experimentally-created negotiation groups." J. of Psych. Studies 14: 117-138.

MALINOWSKI, B. (1922) Argonauts of the Western Pacific. London: Routledge \& Kegan Paul.

MARCH, J. G. and H. A. SIMON (1958) Organizations. New York: John Wiley.

MARSHALL, C. B. (1965) The Exercise of Sovereignty. Baltimore: Johns Hopkins Univ. Press.

MARTIN, L. (1967) The Sea in Modern Strategy. New York: Praeger.

MAUS, M. (1925) The Gift. Paris: Presses Universitaires Françaises.

MAXWELL, G. and D. SCHMITT (1968) “Are 'trivial' games the most interesting psychologically?" Behavioral Sci. 13.

MITTELMARK, M. B., R. M. ROZELLE, and D. DRUCKMAN (1977) “Accountability and role behavior of bargainers." Presented at the annual meeting of the American Psychological Association, San Francisco.

MORLEY, I. E. and G. M. STEPHENSON (1970) "Formality in experimental negotiations: a validation study." British J. of Psychology 61: 363-384.

NAKANE, C. (1970) Japanese Society. Berkeley: Univ. of California Press.

NASH, J. F. (1953) “Two person cooperative games." Econometrica 21: 128-140.

_-_ (1950) "The bargaining problem." Econometrica 18: 155-162.

NEUSTADT, R. E. (1960) Presidential Power: the Politics of Leadership. New York: John Wiley.

NEWHOUSE, J. (1973) Cold Dawn: the Story of SALT. New York: Holt, Rinehart \& Winston.

Newsweek (1972) October 30.

New York Times (1966) October 26: 20.

NICOLSON, H. (1964) Diplomacy. New York: Oxford.

NIERENBERG, G. (1973) Fundamentals of Negotiating. New York: Hawthorn.

Observations on International Negotiations (1971) Transcript of an informal conference, Greenwich, CT: New York: Academy for Educational Development.

OSGOOD, C. E., G. J. SUCI, and P. H. TANNENBAUM (1957) The Measurement of Meaning. Urbana: Univ. of Illinois Press. 
PAINTON, F. C. (1970) "Changing course for Franco's Spain." US News and World Report, November 16.

PARDO, A. (1974) Interview.

_-_ (1968) "Who will control the seabed?" Foreign Affairs 4I: 123-137.

PECQUET, A. (1738) De l'Art de Negocier avec les Souverains. Paris: van Duren.

PEN, J. (1952) “A general theory of bargaining." Amer. Econ. Rev. 1: 29-42.

Pentagon Papers: the Defense Department History of United States Decision Making on Vietnam: Senator Gavel Edition. Boston: Beacon Press.

PERRY, S. E. (1957) "Notes on the role of the national: a social-psychological concept for the study of international relations." $J$. of Conflict Resolution 1: 346-363.

PORTER, G. (1975) A Peace Denied: the United States, Vietnam and the Paris Agreements. Bloomington: Univ. of Indiana Press.

Presidential Science Advisory Committee, Panel on Oceanography (1966) Effective Use of the Sea. Washington, DC: Government Printing Office.

QUANDT, W. B. (1975) "The Middle East," in Wall, 1975.

RAIFFA, H. (1953) "Arbitration schemes for generalized 2-person games," in Kuhn and Tucker, 1953.

RAMBERG, B. (1977) "Tactical advantages of opening positioning strategies: lessons from the seabed arms control talks 1967-1970." J. of Conflict Resolution 21, 4.

RAO, P. and R. L. Miller (1971) Applied Econometrica. Belmont, CA: Wadsworth.

RAPOPORT, A. (1974a) "Prisoner's dilemma: recollections and observations,"pp. 17-34 in A. Rapoport (ed.) Game Theory as a Theory of Conflict Resolution. Dordrecht: D.

Reidel Publishing.

- - (1974b) Conflict in Man-Made Environment. Baltimore: Penguin.

-_- (1966) Two-Person Game Theory. Ann Arbor: Univ. of Michigan Press.

-__ (1965) "Models of conflict: cataclysmic and strategic," in Conflict in Society Symposium, London: CIBA Foundation.

-__ (1960) Fight, Games and Debates. Ann Arbor: Univ. of Michigan Press.

RICHARDSON, L. F. (1960) Arms and Insecurity. Pittsburgh: Boxwood.

RIKER, W. H. (1962) The Theory of Political Coalitions. New Haven: Yale Univ. Press.

- - and W. J. ZAVOINA (1970) "Rational behavior in politics: evidence from a 3-person game." Amer. Pol. Sci. Rev. 64: 48-60.

ROBINSON, W. S. (1957) "The statistical measure of agreement." Amer. Soc. Rev.

22: 17-25.

ROKEACH, M. (1960) The Open and Closed Mind. New York: Basic Books.

ROSENTHAL, R. and R. ROSNOW (1969) Artifacts in Behavioral Research. New York: Academic.

ROSS, A. M. (1954) "The natural history of the strike," in Kornhauser, Dubin, and A. M. Ross (eds.) Industrial Conflict. New York: McGraw-Hill.

RUBIN, J. and B. BROWN (1975) The Social Psychology of Bargaining and Negotiation. New York: Academic.

SAATY, T. L. (1968) Mathematical Models of Arms Control and Disarnament. New York: John Wiley.

SACHS, M. (1971) Seabed 1969. New York: Worldmark.

- - (1970) Seabed 1968. New York: Worldmark. 
SAWYER, J. and H. GUETZKOW (1965) "Bargaining and Negotiation in International Relations," pp. 464-520 in H. Kelman (ed.) International Behavior. New York: Holt, Rinehart \& Winston.

SCHELLING, T. C. (1960) The Strategy of Conflict. Cambridge: Harvard Univ. Press. SHAPLEY, L. S. (1953) "A value for n-person games," in Kuhn and Tucker, 1953.

SHEEHAN, E.R.F. (1976) "Step by step in the Middle East." Foreign Policy 22: 3-70. SHAW, J. and C. THORSLUND (1975) "Varying patterns of reward cooperation."

J. of Conflict Resolution 19.

SHAW, M. E. (1976) Group Dynamics: the Psychology of Small-Group Behavior. New York: McGraw-Hill.

SHERIF, M. (1936) The Psychology of Social Norms. New York: Harper \& Row.

O. J. HARVEY, B. J. WHITE, W. R. HOOD, and C. W. SHERIF (1961)

Intergroup Conflict and Cooperation: the Robber's Cave Experiment. Norman: Univ. of Oklahoma Press.

SIEGEL, S. and L. FOURAKER (1960) Bargaining and Group Decision-Making. New York: McGraw-Hill.

SPECTOR, B. I. (1977a) "Psychological impacts on negotiation: an empirical analysis." Presented at the annual meeting of the International Studies Association, St. Louis, MO.

(1977b) "Negotiation as a psychological process." J. of Conflict Resolution 21, 4. (1976a) "A social-psychological model of position modification: Aswan" in

I. W. Zartman, 1976.

(1976b) "Power positions among nations: an analysis of responsiveness to foreign policy power strategies." Presented to the annual meeting of the Peace Science Society (International), southern section.

_- (1975) "The effects of personality, perception, and power on the bargaining process and outcome." Ph.D. dissertation, New York University.

SMOKER, P. (1965) "Trade, defense and the Richardson theory of arms races: a seven nation study." J. of Peace Research 2: 161-176.

SNYDER, G. H. (1971) "Prisoner's dilemma and 'chicken' models in international politics." Inter. Studies Q. 15: 66-103.

STAHL, I. (1972) Bargaining Theory. Stockholm: Economic Research Institute.

STECH, F. (1977) "Communicated influence effects on duopoly bargaining behavior." Ph.D. dissertation, University of California at Santa Barbara.

STEIN, M. (1963) "Explorations in typology," in R. W. White (ed.) The Study of Lives. New York: Atherton.

STEINBRUNNER, J. D. (1974) The Cybernetic Theory of Decision: New Dimensions of Political Analysis. Princeton: Princeton Univ. Press.

STERN, L. W., B. STERNTHAL, and G. S. CRAIG (1975) "Strategies for managing interorganizational conflict: a laboratory paradigm." J. of Applied Psychology 60: $472-482$.

STEVENS, C. C. (1963) Strategy and Collective Bargaining. New York: McGraw-Hill. Stockholm International Peace Research Institute (1970) SIPRI Yearbook of World Armament and Disarmament 1969-1970. Stockholm: Almqvist and Wiksells.

STORY, J. (1973) "Spanish Foreign Policy 1945-1970." Ph.D. dissertation, Johns Hopkins University. 
STROTZ, R. H. (1956) “Myopia and inconsistency in dynamic utility maximization." Rev. of Econ. Studies 23: 165-180.

SWINGLE, P. [ed.] (1970) The Structure of Conflict. New York: Academic.

SZULC, T. (1974) “How Kissinger Did It." Foreign Policy 15: 21-69.

TER HUNE, K. (1974) "'Wash-in,' 'wash-out,' and systemic effects in extended prisoner's dilemma." J. of Conflict Resolution 18.

- - and J. FIR ESTONE (1966) "Studies of personality in cooperation and conflict." Presented at the North American Peace Research Conference of the Peace Research Society (International).

Time (1973) February 5: 13.

TRACY, B. H. (forthcoming) "Bargaining as trial and error: the case of the Spanish base negotiations 1963-1970," in I. W. Zartman (ed.) Bargaining and Negotiation: Theory and Analysis. Beverly Hills: Sage.

___ (1975) "Bargaining models and base negotiations." Ph.D. dissertation, Johns Hopkins University.

TURK, H. and M. J. LEFCOWITZ (1962) "Toward a theory of representation between groups." Social Forces 40: 337-341.

United Nations (1960) Second UN Conference on the Law of the Sea. New York: United Nations.

-_- (1958) UN Conference on the Law of the Sea. New York: United Nations.

U.S. Arms Control and Disarmament Agency (1971) Documents on Disarmament 1970. Washington, DC: Government Printing Office.

___ (1970) Documents on Disarmament 1968. Washington, DC: Government Printing Office.

___ (1969) Documents on Disarmament 1968. Washington, DC: Government Printing Office.

U.S. Committee on Government Operations, Subcommittee on National Security (1972) International Negotiation Part 7. Washington, DC: Government Printing Office.

-_- (1970) International Negotiation: American Shortcomings in Negotiating with Communist Powers. Washington, DC: Government Printing Office.

U.S. Congress Committee on Armed Services, Preparedness Investigating Subcommittee (1962) Arms Control and Disarmament. Washington, DC: Government Printing Office.

U.S. Department of State, Bureau of Research and Intelligence (1974) National Claims to Maritime Jurisdictions. Washington, DC: Government Printing Office.

U.S. Senate (1970a) Committee on Foreign Relations, Subcommittee on United States Security Agreements and Commitments Abroad, Hearings.

___ (1970b) Agreement Between the United States and Spain. Report 91-1425. Washington DC: Government Printing Office.

VIDMAR, N. (1971) "Effects of representational roles and mediators on negotiating effectiveness." J. of Personality and Social Psychology 17: 48-58.

- $(1970)$ "Forces affecting success in negotiating groups," Behavioral Sci. 15: 154-163.

_-_ and J. E. McGRATH (1965) "Role assignment and attitudinal commitment as factors in negotiation." Technical report no. 3. Urbana: Univ. of Illinois.

VINACKE, W. (1969) "Variables in experimental games: toward a field theory." Psych.

Bull. 71. 
VINOKUR, A. and E. BERSTEIN (1974) "Effects of partially shared persuasive arguments on group-induced shifts.” J. of Personality and Social Psychology 29: 305-315.

VINOKUR, A., TROPE, and E. BERNSTEIN (1975) “A decision-making analysis of persuasive argumentation and choice-shift effect." J. of Exper. Psychology 11: 127148.

WADE, L. L. and R. L. CURRY (1971) "An economic model of socio-political bargaining." Amer. J. of Economics and Sociology 30: 383-393.

WALCOTT, C. and P. T. HOPMANN (1975) "Interaction analysis and bargaining behavior." Exper. Study of Politics 4.

WALL, J. A. (1975) "Effects of constituent trust and representative bargaining orientaion on intergroup bargaining." J. of Personality and Social Psychology 31: 1004-1012.

_—_ and J. S. ADAMS (1974) "Some variables affecting a constituent's evaluations of and behavior toward a boundary role occupant." Organizational Behavior and Human Performance 11: 390-408.

WALL, M. M. [ed.] (1975) “International negotiations." J. of International Affairs $9,1$.

WALTON, R. E. (1970) “A problem-solving workshop on border conflicts in East Africa." J. of Applied Behavioral Sciences 6: 453-489.

—— and R. B. McKERSIE (1965) A Behavioral Theory of Labor Negotiations. New York: McGraw-Hill.

WEICK, K. (1965) "Laboratory experimentations with organizations," in J. G. March (ed.) Handbook of Organizations. Chicago: Rand McNally.

WENK, E. (1972) The Politics of the Ocean. Seattle: Univ. of Washington Press.

WHITAKER, A. P. (1961) Spain and the Defense of the West. New York: Harper \& Row.

WINHAM, G. R. (1977a) "Complexity in international negotiation," in D. Druckman (ed.) Negotiations: a Social-Psychological Perspective. New York: Halstead.

-__ (1977b) "Negotiation as a management process." World Politics 30.

- and H. E. BOVIS (forthcoming) "Report on the Slobbovia Negotiations."

WINNEFELD, M. and C. BUILDER (1971) “ASW-now or never," U.S. Naval Institute Proceedings 97: 18-25.

WOLFE, T. W. (1975) The SALT Experience Report R-1686-PR. Santa Monica, CA: Rand.

WOODWARD, E. L., R. BUTLER, and M. LAMBERT [eds.] (1949) Documents on British Foreign Policy 1919-1939). London: HMSO: 2.

WRIGHTSON, M. (1976) "The documentary coding method," in R. Axelrod (ed.) Structure of Decision: the Cognitive Maps of Political Elites. Princeton, NJ: Princeton Univ. Press.

YOUNG, O. [ed.] (1975) Bargaining. Urbana: Univ. of Illinois Press. (1967) The Politics of Force: Bargaining During International Crisis. Princeton: Princeton Univ. Press.

ZAGARE, F. C. (1977a) "Deception in 3-person games: an analysis of strategic misrepresentation in Vietnam," Ph.D. dissertation. New York University.

_- (1977b) "A game-theoretic analysis of the Vietnam negotiations: Preferences and strategies 1968-1973.” J. of Conflict Resolution 21, 4. 
ZARTMAN, I. W. (1977) "Negotiation as a joint decision-making process." J, of Conflict Resolution 21, 4.

[ed.] (1976) The 50\% Solution: How to Bargain Successfully with Hijackers, Strikers, Bosses, Oil Magnates, Arabs, Russians, and Other Worthy Opponents in this Modern World. New York: Doubleday Anchor.

(1975) "Negotiations: theory and reality." J. of Inter. Affairs 9: 69-77.

(1974) "The political analysis of negotiation." World Politics 26: 385-399.

(1971) The Politics of Trade Negotiations Between Africa and the European

Economic Community. Princeton: Princeton Univ. Press.

and M. BERMAN (forthcoming) The Practical Negotiator.

ZECHMEISTER, K. and D. DRUCKMAN (1973) "Determinants of resolving a conflict of interest: a simulation of political decision-making." J. of Conflict Resolution 17: 63-88.

ZUEThEN, F. (1930) Problems of Monopoly and Economic Warfare. London: Routledge \& Kegan Paul.

\section{CALL FOR PAPERS \\ INTERNATIONAL CONFERENCE ON APPLIED GAME THEORY}

Institute for Advanced Studies, Vienna

June $12-15,1978$

Papers will be considered that involve serous applodtions of game theory to the social sciences. natural sciences. or humanities All papers should involve the development and application of a gametheoretc model to some real-world phenomend or processes No papers of purely muthematual interest will be acceptable

Papers must be written in Enghsh, be prevously unpublished, and be completed at least one month proor to the Conference It is expected that the Conference pupers will he published in d volume after the conference

Financas support for participants at the Conference will be provided It is anticipited that financial assistance for travel will also be aysulable

The Internaliond Conference on Apphed Game Theury is co-sponsored by the Instutute for Advanced Studies, Vienna, and the Vew York Unversity Center for Applied Economics To be considered for acceptance at the Conference. abstrats should be submulted no later than January 1, 1978 and find papers no later than April 1. 1978 to onc of the following (o)-directors of the Conterence:

\section{Professor Steven J Brams}

Department of Pohtics, Vew York Uinuversity,

25 Waverly Place, New York, N Y 10003

Professor Andrew Sthotter

Department of Economics. New York University. 538 Tisch Hall, Washungton Square.

New York. N Y 10003

Dr Gerhard Schwodiduer

Institute for Adyanced Studies

Stumpergasse 56, A-1060 Vienna. Austrid

Decisions will be made unly on the basts of find papers In all organizational matters. pledse contact Dr Schwodiduer 